Agrovoc descriptors: Malus pumila, apples, fruits, storage, ripening, maturity, organoleptic properties, phenolic compounds, organic acids, chemicophysical properties, solubility, solids, firmness, organic acids, sugars, epidermis, antioxidants

\title{
Changes in the inner quality parameters of apple fruit from technological to edible maturity
}

\author{
Maja MIKULIČ PETKOVŠEK ${ }^{1}$, Franci ŠTAMPAR ${ }^{2}$, Robert VEBERIČ ${ }^{3}$
}

Received October 10, 2008; accepted April 3, 2009.

Delo je prispelo 10. oktobra 2008; sprejeto 3. aprila 2009.

\begin{abstract}
The changing dynamics of organic acids, sugars, phenolics and antioxidant potential in apples from technological to edible maturity was studied. During the time of storage, the content of citric and malic acids generally decreased. The content of sucrose, fructose and glucose decreased significantly in some varieties, while it increased in others. The content of total sugars changed only slightly over the storage period. In the apple pulp, the content level of single phenolics generally changed to a minor extent during storage. In the peel, the content levels of the rutin and quercetin-3rhamnoside flavonoids remained generally constant during storage, while the level of $p$-coumaric acid increased slightly; on the other hand, the content levels of epicatechin and catechin decreased. In the pulp of most cultivars, there was no significant decrease in total phenolics at edible maturity. In contrast, the apple peel usually has a higher content level of total phenolics at edible maturity than at the time of technological maturity. Therefore, the antioxidant activity of the peel increased from technological to edible maturity.
\end{abstract}

Key words: fruit, storage, technological maturity, edible maturity, firmness, soluble solids, phenolic compounds, organic acids, sugars

\section{IZVLEČEK}

Proučevali smo dinamiko spreminjanja organskih kislin, sladkorjev, fenolnih spojin in antioksidativnega potenciala jabolk od tehnološke do užitne zrelosti. Vsebnost citronske in jabolčne kisline se je med skladiščenjem na splošno zmanjševala. Vsebnost saharoze, fruktoze in glukoze se je $\mathrm{v}$ času skladiščenja pri nekaterih sortah značilno zmanjšala, pri drugih pa povečala. Vsebnost skupnih sladkorjev se je med skladiščenjem le malo spreminjala. Na splošno se je vsebnost posameznih fenolov v pulpi jabolk v času skladiščenja le malo spreminjala. V kožici je ostala vsebnost flavonoidov rutina in kvercetin-3-ramnozida $\mathrm{v}$ obdobju skladiščenja približno enaka, vsebnost $p$-kumarne kisline se je malo povečala, medtem ko se je količina epikatehina in katehina zmanjšala. Pri večini sort je opaziti $\mathrm{v}$ pulpi neznačilno zmanjšanje skupnih fenolov v užitni zrelosti. Nasprotno je kožica jabolk pri večini sort $\mathrm{v}$ užitni zrelosti imela večjo vsebnost skupnih fenolov kot $v$ tehnološki zrelosti. Iz tega tudi izhaja, da se je antioksidativna aktivnost kožice od tehnološke do užitne zrelosti povečala.

Ključne besede: plodovi, skladiščenje, tehnološka zrelost, užitna zrelost, trdota, suha snov, fenolne spojine, organske kisline, sladkorji

\section{INTRODUCTION}

The attractiveness of fruit to consumers is determined by visual attributes that include appearance, size, uniformity, colour and freshness, as well as non-visual attributes such as taste, aroma, flavour, firmness (texture), nutritional value and healthiness. Among these attributes, firmness and aroma appear to be the most important for consumers (Awad and de Jager, 2002; Aaby et al., 2002). Sugars, organic acid and phenolic compounds all contribute to the aroma of apples. Fresh fruit contains these nutritional and healthy

\footnotetext{
1 University of Ljubljana, Biotechnical Faculty, Jamnikarjeva 101, Ljubljana, Slovenia; E-mail: maja.mikulic-petkovsek@bf.uni-lj.si

2 University of Ljubljana, Biotechnical Faculty, Jamnikarjeva 101, Ljubljana, Slovenia; E-mail: franci.stampar@bf.uni-lj.si

3 University of Ljubljana, Biotechnical Faculty, Jamnikarjeva 101, Ljubljana, Slovenia; E-mail: robert.veberic@bf.uni-lj.si
} 
constituents: minerals, vitamins and phytochemicals, such as carotenoids, flavonoids and phenolic acids. Consumers are becoming more interested in the content of these health-promoting compounds in fruit because of their antioxidant activity (Wang et al., 1996; Robards et al., 1999; Gil et al., 2002). Apple peel, in general, had a 2-9 times higher content level of both individual phenolics and total phenolics (Mikulič Petkovšek et al., 2007). These quantitative differences occurred mainly because of flavonol glycosides as well as high levels of catechins and chlorogenic acid in the peel (Escarpa and Gonzalez, 1998). In particular, phenolics in apple skin showed a much higher contribution to the total antioxidant and antiproliferative activity of the whole apple than those in apple flesh (Wolfe et al., 2003).

Organic acids, sugars and phenolic compounds are produced through metabolic pathways during ripening, harvest, post-harvest and storage, and they are influenced by many factors related to species, variety and technological treatment (Ackerman et al., 1992; Boylston et al., 1994). Storage at reduced oxygen concentrations, i.e. controlled atmosphere (CA), will prolong the life of apples. During CA and lowtemperature conditions, the general appearance of stored apples can be maintained for a long period of time, while the production of aromatic compounds decreases (Boylston et al., 1994; Brackmann et al. 1994).

Patterns of change in organic acid, carbohydrates and phenolics during storage are variable (Roth et al., 2007). Roth et al. (2007) reported that sucrose content in apples decreased during storage, while glucose and sorbitol content levels increased. Piretti et al. (1994) found that epicatechin, quercetin glycosides and procyanidins in 'Granny Smith' generally decreased during storage. Similar results were reported for the 'Boskoop' apples about decreasing the concentrations of catechin, epicatechin and phenolic acids (Mosel and Herrmann, 1974). In contrast, some researchers found that the content of phenolics increased during storage (Burda et al., 1990; Napolitano et al., 2004). The majority of researchers reported that no change occurred in the concentrations of simple phenols (mainly chlorogenic acid), flavonoids and anthocyanin during storage (Perez-Ilzarbe et al., 1997; Awad and de Jager, 2000; Golding et al., 2001).

The evidence available on postharvest behaviour of natural compounds in apples is partly conflicting and needs further study. The purpose of this investigation was to find whether the parameters of inner quality of apple fruit changed during storage. At the time of technological and edible maturity of fruit, their maturity parameters were measured, the content of organic acids, sugars and sorbitol was determined as well as the content of individual phenolic substances, total phenols and antioxidant activity. Our interest was in determining whether the content of phenolics in apples decreased from their technological to their edible maturity. Furthermore, we wanted to ascertain if there was a difference in the parameters studied between the group of varieties resistant to apple scab and the susceptible ones.

\section{MATERIALS AND METHODS}

\subsection{Plant material and growing conditions}

This experiment was carried out in 2005. Fruit samples for the experiment were taken from apple trees grafted on M9 rootstock growing in Ljubljana (Central Slovenia). Ten trees of three scab resistant cultivars ('Goldstar', 'Rubinola' and 'Topaz') and three scab susceptible cultivars ('Braeburn', 'Jonagold' and 'Golden Delicious') were used in the experiment. Because of favourable weather conditions for apple scab development, the susceptible cultivars were protected against this disease with fungicides; meanwhile, the resistant cultivars were not sprayed. For susceptible cultivars left without spraying, the damage on the fruit caused by apple scab would have been severe, and this comparison would have been impossible. The set-up of such an experiment is also in accordance with normal orchard practices. From each tree, 10 fruit samples were picked (100 fruit samples of each cultivar in total). Fifty of these were immediately used for analysis, the remaining 50 were placed in cold storage $\left(2{ }^{\circ} \mathrm{C}\right.$, presence of $\mathrm{O}_{2}$ ) until they reached edible maturity. Immediately after harvest, the fruit were frozen in liquid nitrogen and stored at $-20^{\circ} \mathrm{C}$ until preparation of the samples.
The apples were analysed at two dates in order to determine the content of organic acids, sugars, phenolic compounds and antioxidative potential. The first date coincided with the time of technological maturity of the individual variety and the second one with the edible maturity of the variety. Fruit sampling was performed at technological maturity, which was evaluated using the starch iodine test.

\subsection{Maturity and standard quality parameter analyses}

Fifty apples of each cultivar were used for measurement, both at harvest and after removal from cold storage. The skin was removed using slicers to a 1-mm cutting depth, and flesh firmness was then measured with a penetrometer equipped with an 11-mm diameter plunger tip; the results were expressed in $\mathrm{kg} / \mathrm{cm}^{2}$. Soluble solids were measured in the juice pressed from the whole fruit. Soluble solids concentration was measured using a digital refractometer (Atago CO., LTD; Japan), and the results were expressed in 
${ }^{\circ}$ Brix. Starch index was determined with the iodine solution, where the Eurofru scale was used.

\subsection{Extraction and determination of sugars, organic acids and phenolic compounds}

Sugars and organic acids were prepared as described by Mikulič Petkovšek et al. (2007). The analysis of sugar and organic acid content levels was carried out using highperformance liquid chromatography (HPLC) (Thermo Separation Products equipment, USA). The separation of sugars was carried out using a Rezex RCM-monosaccharide column $(300 \times 7.8 \mathrm{~mm})$ (Phenomenex, USA). The mobile phase was bi-distilled water, and a refractive index (RI) detector was used for monitoring the eluted carbohydrates according to Dolenc-Šturm et al. (1999) with minor changes. Organic acids were analysed using the Aminex HPX-87H column $(300 \times 7.8 \mathrm{~mm})$ (Bio-Rad, USA) associated with a UV UV-detector, as described by Dolenc-Šturm et al. (1999).
The elution solvent was $4 \mathrm{mM}$ sulphuric acid in bi-distilled water. Phenols were extracted and analyzed using the method of Escarpa and Gonzalez (2000). The content of individual phenols was analysed with the HPLC-PDA system using the Phenomenex Gemini C18 column, and the content of total phenols followed the method with Folin- Ciocalteu reagent (Singleton and Rossi, 1965). Absorption was measured at 765 $\mathrm{nm}$ on the UV-VIS spectrophotometer. The content of individual phenols was expressed in $\mathrm{mg} / \mathrm{kg}$ of sample used. The content of total phenols was expressed in equivalents of gallic acid per $\mathrm{kg}$ of fresh sample. Antioxidative activity was measured spectrophotometrically, and the result was expressed in the equiv. of ascorbic acid per $100 \mathrm{~g}$ of sample (Brand-Williams et al., 1995). Data were processed statistically using the Statgraphic Plus 4.0 program. One-way analysis of variance $(p<0,05)$ was used. The differences between cultivars were tested using the Duncan test and, between maturity dates, using the LSD test at the 0.05 significance level.

\section{RESULTS AND DISCUSSION}

\subsection{Maturity parameters of different apple varieties at the time of technological and edible maturity}

As seen in Figure 1-A, the firmness of fruit in all the varieties was significantly reduced over the storage period. Numerous enzymes that cause the cell walls and lamellas to disintegrate during storage are the reason for the reduced fruit firmness. In the process, calcium from the cell walls is transferred to the interior of cells (Teixeira and Ferreira, 1993). In accordance with our results, a decrease in firmness during storage was reported by Drake et al. (1988), Albanese et al. (2007) and Roth et al. (2007), explaining that firmness was reduced at the expense of a water content decrease in fruit. The 'Braeburn' variety was outstanding for the greatest firmness at technological maturity, with values of $10 \mathrm{~kg} / \mathrm{cm}^{2}$.

The content of total soluble matter includes soluble sugars, organic acids, sorbitol, some inorganic substances and vitamins and is an important indicator of the maturity level. The content of total soluble matter in fruit $\left({ }^{\circ} \mathrm{Brix}\right)$ was higher at edible maturity if compared with the the time of technological maturity. The fruit specimens of the 'Braeburn', 'Rubinola' and 'Topaz' varieties had a significantly higher content of total soluble matter at the time of edible maturity than at technological maturity (Fig. 1-B). An increase in total soluble matter of apples during storage was also reported by Drake et al. (1988). Napolitano et al. (2004) measured a higher content of dry matter in some varieties and lower dry matter content in others after 4 months of storage. The increase in total soluble matter may be explained by starch decomposition.
Differences in starch index between the two dates of technological and edible maturity were significant in all varieties. So, the fruit at technological maturity had lower values on the starch index (according to the 1-10 Eurofru scale), while at edible maturity, values on the starch index were statistically higher, which means that the fruit contained less starch (Fig. 1-C). With fruit ripening, the starch content decreases as it hydrolyses into sugars.

\subsection{The content of sugars, sorbitol and organic acids in fruit at the time of technological and edible maturity}

In the 'Braeburn', 'Rubinola' and 'Golden Delicious' varieties, the content of sucrose at the time of edible maturity increased significantly in comparison to the content of sucrose at technological maturity (Fig. 2-A). In the 'Jonagold' and 'Topaz' varieties, it decreased significantly. Šturm (2001) also reported an increase in the sucrose content level of apples during storage. In contrast, Roth et al. (2007) reported a decline in sucrose content during storage. The content of glucose also increased significantly or remained the same in the majority of varieties (Fig. 2-B). An increase in glucose content in the fruit of 'Elstar' and 'Jonagold' varieties at the time of storage was also reported by Ackermann et al. (1992) and Roth et al. (2007). At the time of edible maturity, the content of fructose increased significantly in comparison to its content at picking in the 'Braeburn', 'Rubinola' and 'Golden Delicious' varieties, and it decreased significantly in the 'Goldstar' and 'Topaz' varieties (Fig. 2-C). A higher fructose content is reported by Ackermann et al. (1992) after picking of the 'Glockenapfel' apple tree variety. We 
explain the increased fructose content at the time of storage in terms of the decreased water content in the fruit. Statistical differences concerning the content of sorbitol alcohol sugar during technological and edible maturity were shown only in the 'Goldstar' and 'Topaz' varieties (Fig. 2-D). Šturm (2001) reported a considerable decrease in sorbitol content at picking, which was related to the metabolic processes in the fruit and the transformation of sorbitol into other simple sugars, because of which the content during storage increased. The content of total sugars changed only slightly over the storage time (Fig. 2-E). Similarly, Suni et al. (2000) reported that storage had only a minor effect on the average content of sugars and acids in apple fruit.

As a rule, the content of citric and malic acids decreased during storage (Fig. 3-A, 3-B). It is interesting, however, that the content of malic as well as that of citric acid in the 'Rubinola' variety increased significantly at the time of edible maturity in comparison to the time of technological maturity. A gradual decline of malic and citric acids in apple fruit during storage was also reported by Ackermann et al. (1992) and Roth et al. (2007). Malic acid is the main substrate at respiration; therefore, its content decreases more slowly under CA storage conditions (atmosphere with low $\mathrm{O}_{2}$ content) than in the cold-storage chamber with a high oxygen content (Roth et al., 2007). Since malic acid represents the greatest share of total organic acids in the apple fruit, the content of total organic acids during storage decreases. The content of shikimic acid during storage increased in most varieties (Fig. 3-C). Significant differences were calculated only in the 'Braeburn' and 'Rubinola' varieties. At the time of edible maturity, these contained statistically more shikimic acid than at technological maturity. Generally, the content of shikimic acid changed very little between the two dates reported in the study of Šturm (2001).

3.3 The content of phenolic compounds and the antioxidative potential of pulp and skin in various apple varieties at the time of technological and edible maturity

The content level of chlorogenic acid in the pulp during storage remained at approximately the same level (Fig. 4-A), while in the skin its content increased slightly between technological and edible maturity; however, the differences are not significant for all varieties (Fig. 6-A). Similarly to our results, Awad and de Jager (2000) reported that the content of chlorogenic acid in 'Elstar' and 'Jonagold' varieties during storage was relatively stable. In the skin of the 'Red Delicious' variety, a linear increase of chlorogenic acid during the time of storage (MacLean et al., 2006) was detected; similar reports may be found concerning the 'Lady Williams' apple tree variety (Golding et al., 2001).

The content of caffeic and p-coumaric acids in the pulp between the time of picking and the stage of edible maturity remained at approximately the same level in a certain number of varieties and increased in others (Fig. 4-B, 4-C). Napolitano et al. (2004) also report an increase in the caffeic acid content level in the apple pulp. In the skin of some varieties, the content levels of the caffeic and $p$-coumaric acids increased, while it decreased in other varieties (Fig. 6-B, 6-C). Golding et al. (2001) reported that the dynamics of caffeic and ferulic acids in apples was similar to the dynamics of chlorogenic acid, its content level reaching a peak after 3 months of storage with no further changes in metabolism.

In the majority of varieties, the catechin content in the pulp was slightly higher during storage, but the differences were not statistically significant (Fig. 4-D). An increase of catechin in apple pulp during the 3month storage period was reported by Napolitano et al. (2004). In the skin, a decreasing trend in catechin content during storage was noticed for 'Golden Delicious' and 'Rubinola' cultivars (Fig. 6-D). The content level of epicatechin in pulp from technological to edible maturity was slightly higher in certain varieties and lower in others (Fig. 5-A). Napolitano et al. (2004) also reported an increase of epicatechin in apple pulp during storage. In the skin, a significant decrease in epicatechin content was noticed between the two dates of technological and edible maturity in the 'Goldstar', 'Rubinola', 'Topaz' and 'Golden Delicious' varieties (Fig. 6-E). Generally, it may be confirmed that the content of the flavan-3-ols catechin and epicatechin in fruit skin decreased during storage. Similar results were found by Burda et al. (1990) and Golding et al. (2001), i.e. that, generally, the content levels of catechin and epicatechin increased in the first two months of storage, but later they gradually decreased or remained constant. During storage, the content of phloridzin in the pulp varied very little (Fig. 5-B), while in the skin its content increased in some varieties and decreased in others (Fig. 6-F). Napolitano et al. (2004) also found minimal oscillations in the phloridzin content level during apple storage. Golding et al. (2001) reported on an increase of the phloridzin content in the skin of 'Crofton' and 'Lady Williams' varieties during storage, while in the 'Granny Smith' variety its quantity during storage remained approximately at the same level or suffered a slight decline.

Among flavonols we determined the content of rutin and quercetin-3-rhamnoside (quercitrin). The content of quercetin-3-O-rutinoside (rutin), quercetin-3-O- 
galactoside (hyperin) and quercetin-3-O-glucoside (isoquercitrin) was expressed as an equivalent of rutin. The content of rutin in the skin changed only slightly during storage (Fig. 7-A). Rutin was not identified in apple pulp. Similarly, the content of quercetin-3rhamnoside changed only slightly during storage (Fig. 7-B). From the results it is evident that the content of both flavonoids, rutin and quercitrin, did not change essentially during storage, which was also reported by Golding et al. (2001).

In the apple pulp, the content of individual phenolic substances changed insignificantly during storage; consequently, the content of total phenols between the two dates changed very little, too. In the majority of varieties, the total phenols remained on a constant level in apple pulp (Fig. 5-G). In contrast, apple skin at edible maturity had a higher content of total phenols than the skin at technological maturity (Fig. 7-C). Leja et al. (2003) also reported a $30 \%$ increase in total phenols in the skin of the 'Jonagold' and 'Shampion' apple varieties during storage. A particularly extreme increase in total phenols occurred in apples stored in an ordinary cold-storage chamber $\left(0{ }^{\circ} \mathrm{C}\right.$, presence of air $)$ with high ethylene production. The reason for the increase may be attributed to the fruit's respiration and ethylene synthesis (the synthesis is particularly strong at higher temperatures), which stimulate the activity of the enzyme phenylalanine ammonia-lyase (PAL) (PerezIlzarbe et al., 1997). Interestingly, the content levels of all analyzed phenols in the peel of the 'Golden
Delicious' cultivar declined between technological and edible maturity.

Antioxidant activity of pulp increased from technological to edible maturity in certain varieties and decreased in others. Only two differences between the two dates were calculated (Fig. 5-D). Napolitano et al. (2004) reported a significant increase in the antioxidant activity of apple pulp after 3 months of storage. This increase is related to the increase of catechin and phloridzin concentrations in apple pulp. Antioxidant activity of skin increased in all varieties during storage (Fig. 7-D). Leja et al. (2003) indicated that the antioxidant activity doubled during the four-month storage period. The reason for the increase in antioxidant activity is attributed to a higher content of total phenols.

From the results for changes in sugars, organic acids and phenolic substances during storage, no significant differences emerge between the varieties resistant to apple scab and those susceptible to it. Therefore, it cannot be claimed that a connection exists between resistance to apple scab and the dynamics of change in phenolic compounds in apples during storage. The content levels of total sugars and total phenolics in apple pulp changed only slightly over the storage period. In contrast, the apple peel at edible maturity usually has a higher content level of total phenolics than the peel at the time of technological maturity. Hence, the antioxidant activity of peel increased during storage.

\section{ACKNOWLEDGEMENT}

This work is part of the programme Horticulture No P40013-0481 funded by the Slovenian Ministry of Higher Education, Science and Technology.

\section{REFERENCES}

Aaby, K., Haffner, K, Skrede, G. 2002. Aroma quality of Gravenstein apples influenced by regular and controlled atmosphere storage. Lebensm.-Wiss. + Technol. 35: 254259.

Ackermann, J., Fischer, M., Amado, R. 1992. Changes in sugars, acids, and amino acids during ripening and storage of apples (cv. Glockenapfel). J. Agric. Food Chem. 40: 1131-1134.

Albanese, D., Cinquanta, L., Di Matteo, M. 2007. Effect of an innovative dipping treatment on the cold storage of minimally processed Annurca apples. Food Chem. 105: 1054-1060.
Awad, M.A., de Jager A., 2000. Flavonoid and chlorogenic acid concentrations in skin of 'Jonagold' and 'Elstar' apples during and after regular and ultralow oxygen storage. Postharvest Biol. Technol. 20: 15-24.

Awad, M.A., de Jager, A. 2002. Influences of air and controlled atmosphere storage on the concentration of potentially healthful phenolics in apples and other fruits. Postharvest Biol. Technol. 27: 53-58.

Boylston, T.D., Kupferman, E.M., Foss, J.D., Buering, C. 1994. Sensory quality of Gala apples as influenced by controlled and regular athmosphere storage. J. Food Qual. 17: 477-494. 
Brackmann, A., Streif, J., Bangerth, F. 1994. Influence of CA and ULO storage conditions on quality parameters on ripening of preclimateric and climateric harvested apple fruits. 1. Effect on colour, firmness, acidity and solubles solids. Gartenbauwissenschaft 6: 252-257.

Brand-Williams, W., Cuvelier, M.E., Berset, C. 1995. Use of free radical method to evaluate antioxidant activity. Lebensm.-Wiss. + Technol 28: 25-30.

Burda, S., Oleszek, W., Lee, C.Y. 1990. Phenolic compounds and their changes in apples during maturation and cold storage. J. Agric. Food Chem. 38, 8: 945-948.

Dolenc-Šturm, K., Štampar, F., Usenik, V., 1999. Evaluating of some quality parameters of different apricot cultivars usinh HPLC method. Acta Aliment. 28, 4: 297-309.

Drake, S.R., Larsen, F.E., Fellman, J.K., Higgins, S.S. 1988. Maturity, storage quality, carbohydrate, and mineral content of 'Goldspur' apples as influenced by rootstock. J. Am. Soc. Hortic. Sci. 113, 6: 949-952.

Escarpa, A., Gonzalez, M.C. 1998. High-performance liquid chromatography with diode-array detection for the determination of phenolic compounds in peel and pulp from different apple varieties. J. Chromatogr. A, 823: 331-337.

Escarpa, A., Gonzalez, M.C. 2000. Optimization strategy and validation of one chromatographic method as approach to determine the phenolic compounds from different sources. J. Chromatogr. A, 897: 161-170.

Gil, M. I., Tomas-Barberan, F. A., Hess-Pierce, B., Kader, A. A. 2002. Antioxidant capacities, phenolic compounds, carotenoids, and vitamin $\mathrm{C}$ contents of nectarine, peach, and plum cultivars from California. J. Agric. Food Chem. 50: 4976-4982.

Golding, J. B., McGlasson, W. B., Wyllie, S. G., Leach, D. N. 2001. Fate of apple peel phenolics during cold storage. J. Agric. Food Chem. 49: 2283-2289.

Leja, M., Mareszek, A., Ben, J. 2003. Antioxidant properties of two apple cultivars during long-term storage. Food Chem. 80: 303-307.

MacLean, D. D., Murr, D. P., DeEll, J. R., Horvath, C. R. 2006. Postharvest variation in apple (Malus $x$ domestica Borkh.) flavonoids following harvest, storage, and 1MCP treatment. J. Agric. Food Chem. 54: 870-878.

Mikulič Petkovšek, M., Štampar, F., Veberič, R. 2007. Parameters of inner quality of the scab resistant and susceptible apple in organic and integrated production. Sci. hortic. 114: 37-44.

Mosel, H.-D., Herrmann, K. 1974. Changes in catechin and hydroxycinnamic derivatives during development of apples and pears. J. Sci. Food Agric. 25: 251-256.

Napolitano, A., Cascone, A., Graziani, G., Ferracane, R., Scalfi, L., di Vaio, C., Ritieni, A., Fogliano, V. 2004. Influence of variety and storage on the polyphenol composition of apple flesh. J. Agric. Food Chem. 52: 6526-6531.

Perez-Ilzarbe, J., Hernandez, T., Estrella, I., Vendrell, M. 1997. Cold storage of apples (cv. Granny Smith) and changes in phenolic compounds. Z. Lebensm.-Unters.Forsch. 204: 52-55.

Piretti, M.V., Gallerani, G., Pratella, G.C. 1994. Polyphenol fate and superficial scald in apple. Postharvest Biol. Technol. 4: 213-224.

Robards, K., Prenzler, P.D., Tucker, G., Swatsitang, P., Glover, W. 1999. Phenolic compounds and their role in oxidative processes in fruits. Food Chem. 66: 401-436.

Roth, E., Berna, A., Beullens, K., Yarramraju, S., Lammertyn, J., Schenk, A., Nicolai, B. 2007. Postharvest quality of integrated and organically produced apple fruit. Postaharvest Biol. Technol. 45: 11-19.

Singleton, V.L., Rossi, J.A. 1965. Colorimetry of total phenolics with phosphomolybdic-phospholungistic acid reagents. Am. J. Enol. Vitic. 16: 144-158.

Suni, M., Nyman, M., Eriksson, N.-A., Björk, L., Björck, I. 2000. Carbohydrate composition and content of organic acids in fresh and stored apples. J. Sci. Food Agric. 80, 1538-1544.

Šturm K. 2001. Sezonske sprememembe v vsebnosti nekaterih primarnih metabolitov v izbranih organih jablane (Malus domestica Borkh.) $\mathrm{v}$ odvisnosti od vodnega režima in listne površine dreves. Dokt. dis., Ljubljana, Univ. Ljubl., Bioteh. fak., Oddel. agron.: 124 str.

Teixeira A.R.N., Ferreira R.M.B. 1993. Ripening of fruit. In: Encyclopaedia of food technology and nutrition. Macrae R., Robinson R. K., Sadler M. J. (ur.). London, Academic Press, 5: 3933-3940

Wang, H., Cao, G., Prior, R.L. 1996. Total antioxidant capacity of fruits. J. Agric. Food Chem. 44: 701-705.

Wolfe, K., Wu, X., Liu, R.H. 2003. Antioxidant activity of apple peels. J. Agric. Food Chem. 51: 609-614. 
Changes in the inner quality parameters of apple fruit from technological to edible maturity
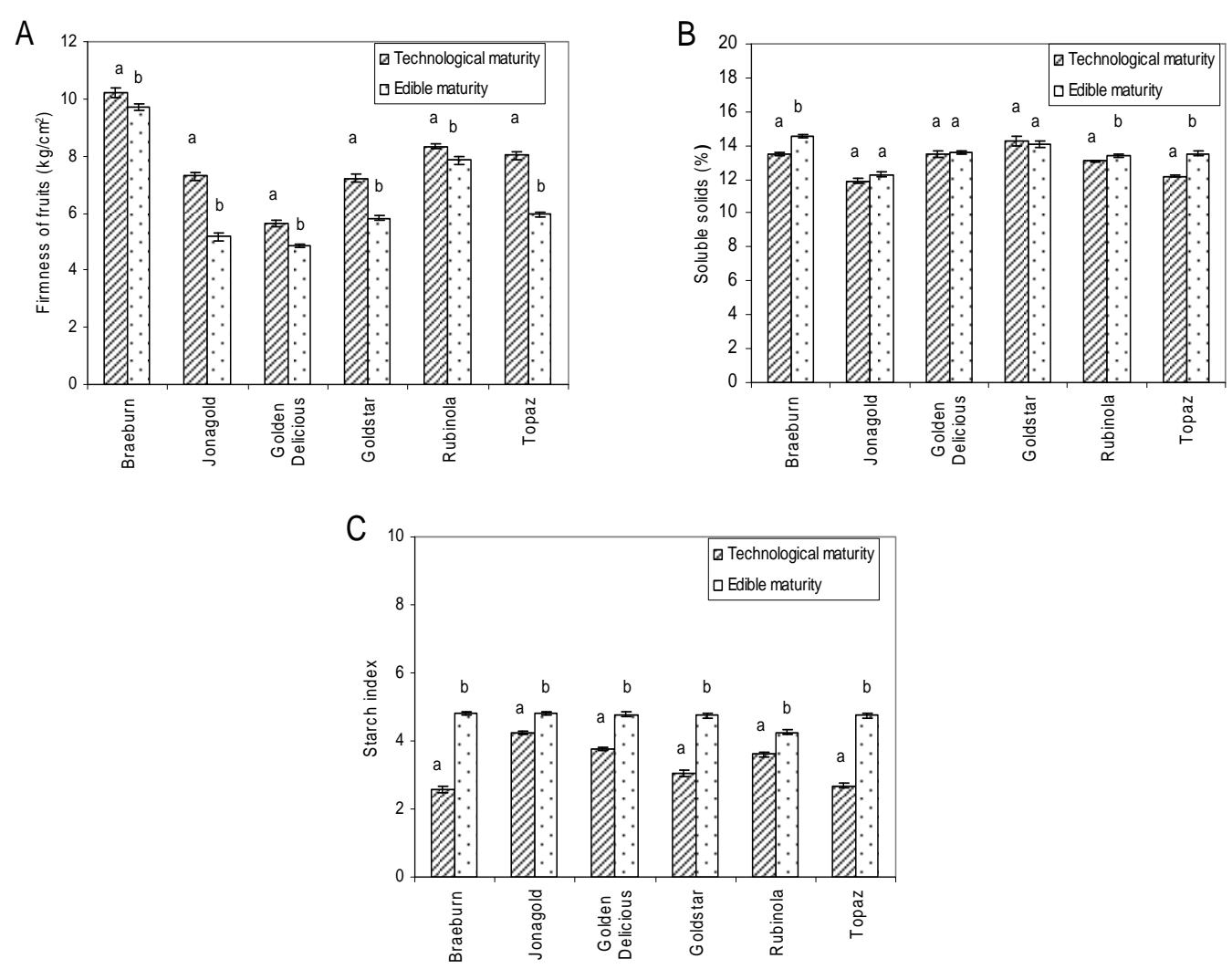

Figure 1: Changes in fruit firmness, soluble solids and starch index of fruit in various apple cultivars during storage. 


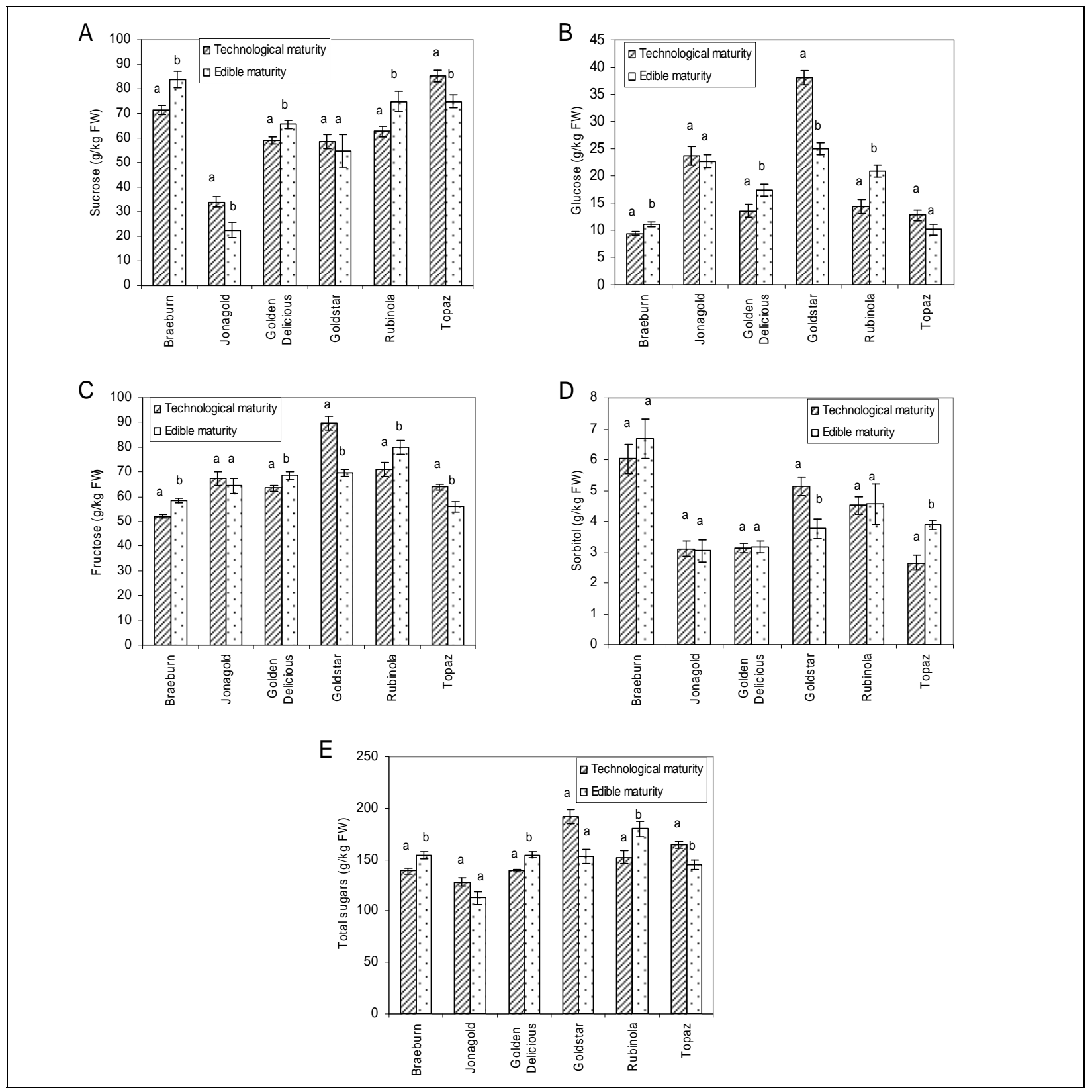

Figure 2: Changes in the sucrose, glucose, fructose, sorbitol and total sugars content ( $(\mathrm{g} / \mathrm{kg} \mathrm{FW})$ of fruit in various apple cultivars during storage. 
Changes in the inner quality parameters of apple fruit from technological to edible maturity
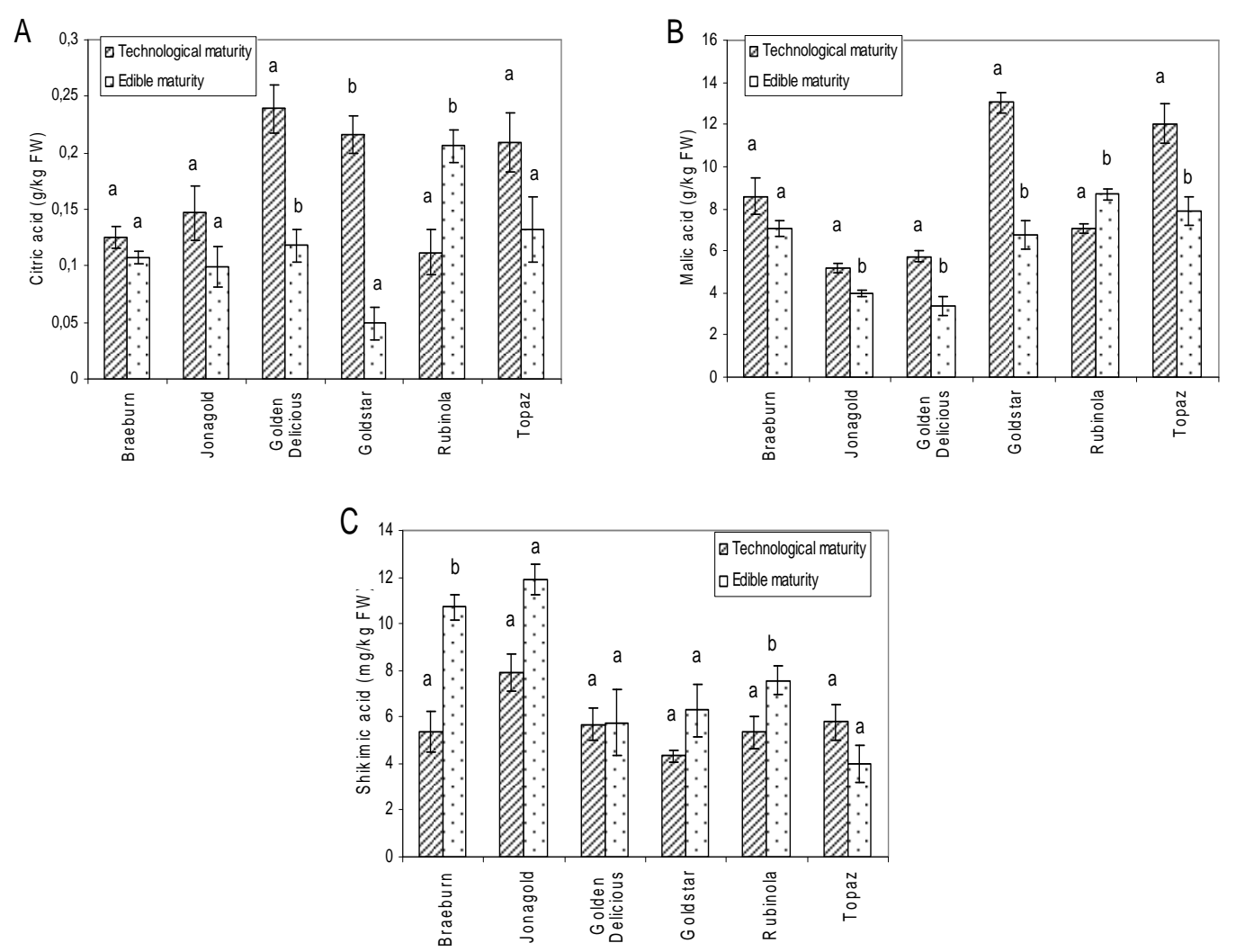

Figure 3: Changes in the content of citric, malic $(\mathrm{g} / \mathrm{kg} \mathrm{FW})$ and shikimic acids $(\mathrm{mg} / \mathrm{kg} \mathrm{FW})$ in fruit of various apple cultivars during storage. 


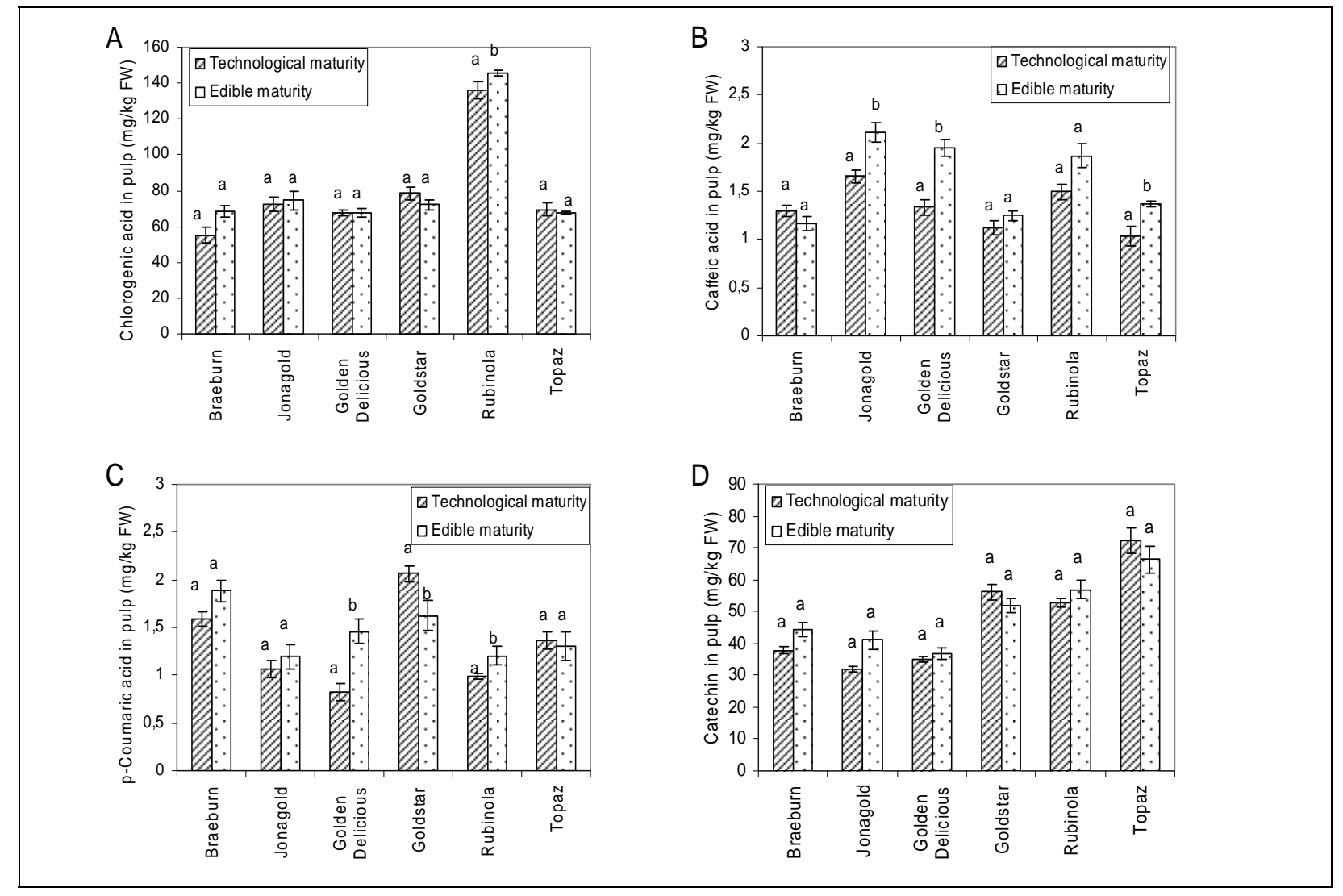

Figure 4: Changes in the content of single phenolics ( $\mathrm{mg} / \mathrm{kg} \mathrm{FW}$ ) in the pulp of various apple cultivars during storage. 


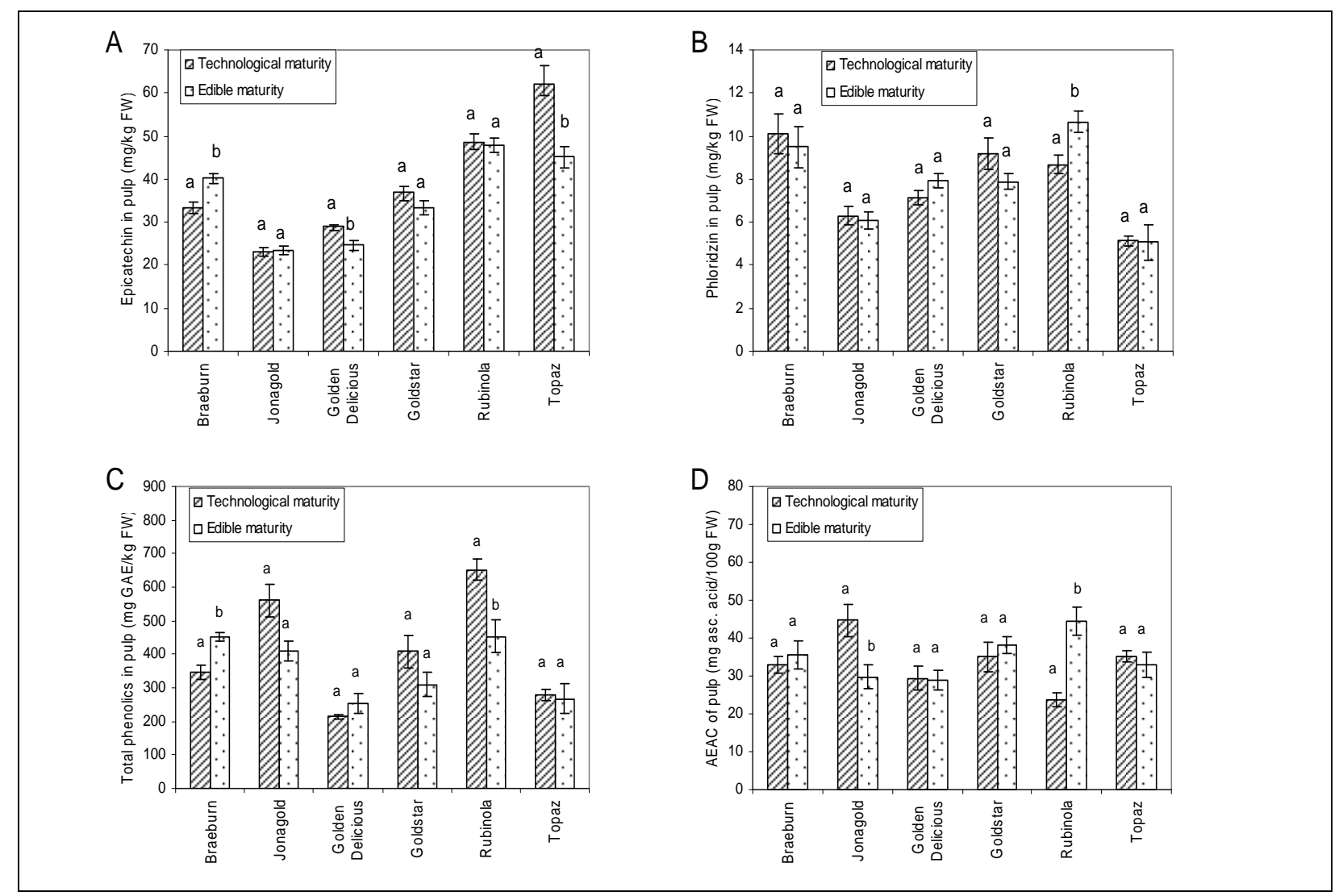

Figure 5: Changes in the content of single phenolics ( $\mathrm{mg} / \mathrm{kg} \mathrm{FW),} \mathrm{total} \mathrm{phenolics} \mathrm{(} \mathrm{mg}$ GAE/ $\mathrm{kg}$ FW) and antioxidant activity (mg/100g FW) in the pulp of various apple cultivars during storage. 


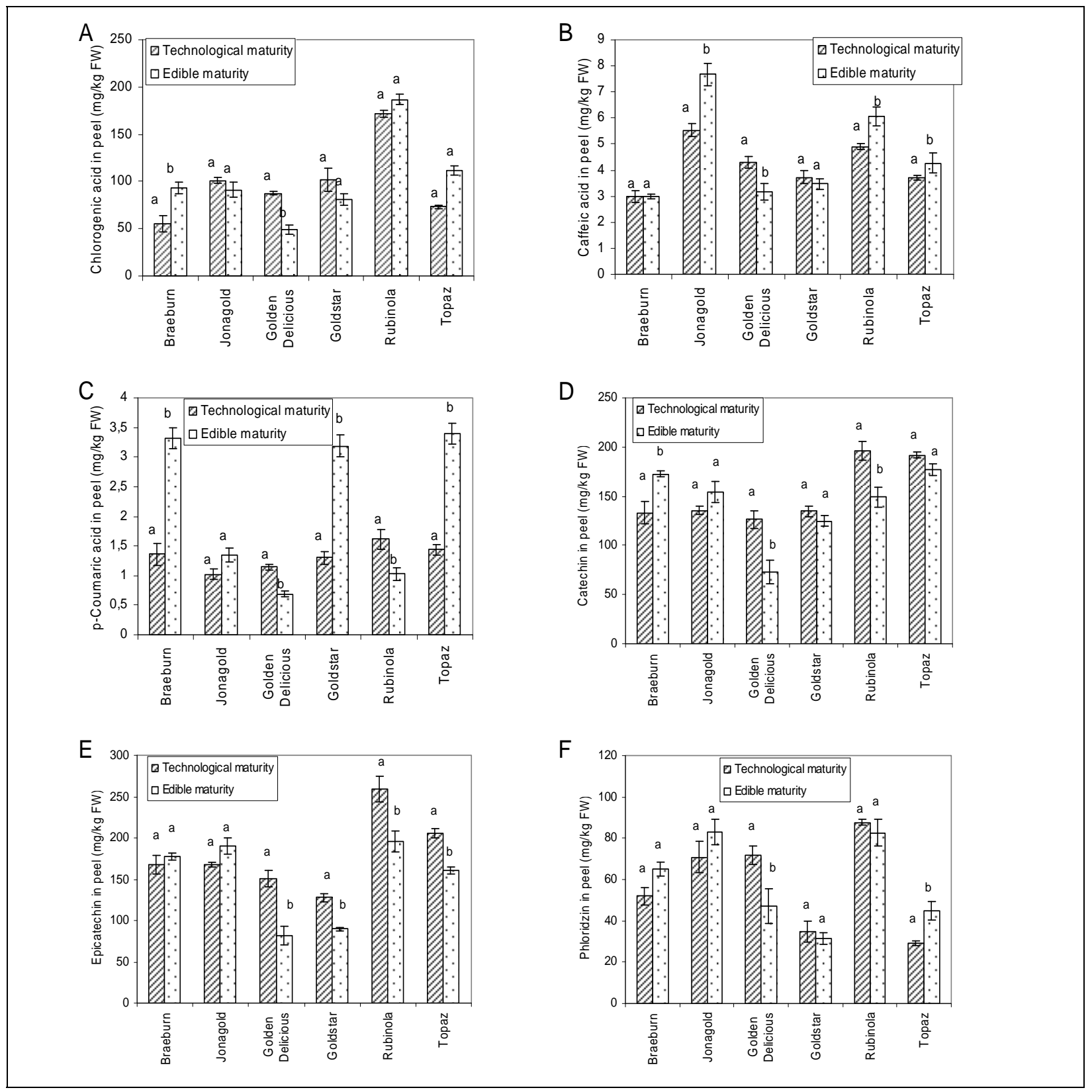

Figure 6: Changes in the content of single phenolics $(\mathrm{mg} / \mathrm{kg} \mathrm{FW})$ in the peel of various apple cultivars during storage. 


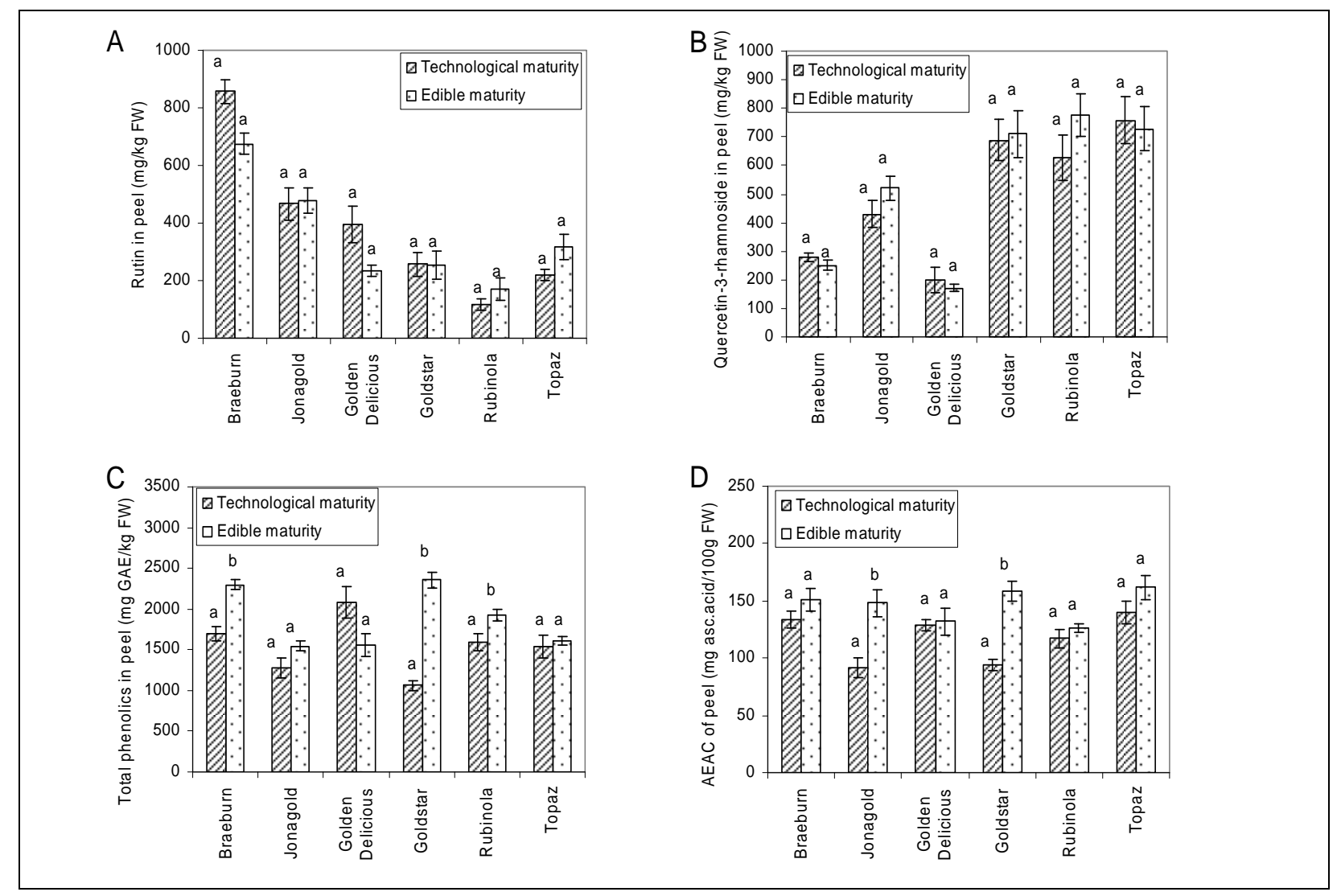

Figure 7: Changes in the content of single phenolics ( $\mathrm{mg} / \mathrm{kg} \mathrm{FW),} \mathrm{total} \mathrm{phenolics} \mathrm{(mg} \mathrm{GAE/} \mathrm{kg}$ FW) and antioxidant activity (mg/100g FW) in the peel of various apple cultivars during storage. 